\title{
Pemberian LCC Mucuna Terhadap Pertumbuhan Dan Hasil Sawi Hijau (Brassica juncea L.) Pada Tanah PMK
}

\author{
Nurhadiah \\ Fakultas Pertanian Universitas Kapuas Sintang \\ Email:dnurhadiah@gmail.com
}

\begin{abstract}
Abstrak: Upaya meningkatkan hasil sayuran sawi hijau di Kabupaten Sekadau dapat dilakukan dengan cara menambahkan bahan organik berupa pembenaman tanaman LCC pada tanah. Ini dilakukan karena sebagian besar kondisi tanah di Kabupaten Sekadau kesuburannya rendah seperti kandungan hara dan bahan organik rendah, serta jumlah mikro organisme sedikit, sementara ketersediaan LLC cukup banyak.. Penelitian ini bertujuan untuk mengetahui pengaruh pemberian LCC Mb terhadap pertumbuhan dan hasil sawi hijau pada tanah PMK; serta mengetahui dosis pemberian LCC Mb yang menghasilkan pertumbuhan serta hasil sawi hijau tertinggi pada tanah PMK. Penelitian ini menggunakan Rancangan Acak Kelompok (RAK) non faktorial. Perlakuan pada penelitian ini adalah LCC Mb yang terdiri atas 7 (tujuh) taraf perlakuan dan tiap taraf diulang 4 (empat) kali. Taraf perlakuan yang dimaksud yaitu: kontrol $\left(\mathrm{L}_{0}\right) ; 0,5 \mathrm{~kg}$ LCC Mb per $\mathrm{m}^{2}\left(\mathrm{~L}_{1}\right) ; 1 \mathrm{~kg}$ LCC Mb per $\mathrm{m}^{2}\left(\mathrm{~L}_{2}\right) ; 1,5 \mathrm{~kg}$ LCC Mb per $\mathrm{m}^{2}\left(\mathrm{~L}_{3}\right) ; 2 \mathrm{~kg}$ LCC Mb per m² $\left(\mathrm{L}_{4}\right)$; $2,5 \mathrm{~kg} \mathrm{LCC} \mathrm{Mb}$ per $\mathrm{m}^{2}\left(\mathrm{~L}_{5}\right)$; dan $3 \mathrm{~kg} \mathrm{LCC} \mathrm{Mb} \mathrm{per} \mathrm{m}^{2}\left(\mathrm{~L}_{6}\right)$. Peubah yang diamati adalah tinggi tanman, jumlah daun dan berat segar tanaman. Data dianalisis dengan analisis sidik ragam dan dilanjutkan dengan uji BNJ pada selang kepercayaan 0,05 dan 0,01. Hasil penelitian diketahui bahwa pemberian LCC Mb berpengaruh terhadap pertumbuhan dan hasil tanaman sawi hijau pada tanah PMK. Pemberian $3 \mathrm{~kg}$ LCC Mb menghasilkan pertumbuhan dan hasil tertinggi tanaman sawi hijau dengan rerata tinggi tanaman $26,58 \mathrm{~cm}$, jumlah daun 13,25 helai, dan berat segar tanaman 0,092 kg per tanaman.
\end{abstract}

Kata Kunci: Tanah PMK, LCC Mb, Sawi Hijau, Pertumbuhan, Hasil.

\section{PENDAHULUAN}

Peningkatan hasil dari suatu komoditas tidak lepas dari peran pengelolaan lahan seperti pemupukan, pengendalian hama dan penyakit, gulma dan penggunaan benih yang memiliki kualitas yang memenuhi standar (Anonim, 2016:1). Sebagian besar para petani telah melakukan atau melaksanakan cara-cara tersebut, namun untuk dibeberapa daerah khususnya di Kabupaten Sekadau produksi tanaman sayuran masih rendah dan belum mampu menyamai produksi sayuran di daerah lain. Berdasarkan data dari Badan Pusat Statistik Kalimantan Barat (2015:197) rata-rata produksi sayuran sawi di Kabupaten Sekadau 5,82 ton per Ha. Produksi ini masih sangat rendah bila dibandingkan dengan produksi sayuran yang sama di Kabupaten Pontianak yang mencapai 17,46 ton per Ha.

Rendahnya produksi sayuran di Kabupaten Sekadau kemungkinan besar dikarenakan cara pengelolaan lahan yang masih belum optimal. Jika dilihat dari jenis tanah yang diolah, sebagian besar sama dengan jenis tanah yang ada di Kabupaten Pontianak yaitu tanah PMK.
Tanah PMK menurut Hakim, dkk. (1998:340) memiliki keterbatasan yaitu miskin hara, derajat kemasaman tanah $(\mathrm{pH})$ rendah, dan miskin bahan organik. Kondisi ini menyebabkan pertumbuhan tanaman menjadi kurang optimal. Hara yang dibutuhkan semasa pertumbuhannya tidak mencukupi. Selain itu, hara di dalam tanah tidak dapat diserap oleh tanaman, karena umumnya hara-hara tersebut terikat dan terjerap oleh kation dan koloid tanah. Tanaman yang ditanam pada tanah yang memiliki keterbatasan ini, umumnya pertumbuhan dan hasilnya kurang maksimal.

Langkah dalam meningkatkan hasil tanaman sayuran di Kabupaten Sekadau dapat diambil dengan memanfaatkan pupuk hijau yang bahannya mudah melapuk dan dapat menyumbangkan hara bagi tanaman. Salah satu jenis pupuk hijau yang dapat diaplikasikan pada lahan yang kurang subur adalah tanaman penutup tanah atau Legume Cover Crop (LCC) dengan cara dibenamkan ke dalam tanah pada saat pengolahan lahan. Salah satu jenis LCC yang ketersediaannya banyak dan mudah diperoleh 
adalah LCC Mucuna bracteata (LCC Mb) khususnya di Kecamatan Sekadau Hulu.

Pemanfaatan LCC Mb sebagai pupuk hijau memberikan keuntungan bagi tanaman karena dapat memperbaiki sifat fisik, kimia dan biologi tanah. Menurut Rambe dkk, (2012:2) menjelaskan bahwa LCC Mb memiliki kandungan unsur hara yang lebih baik dibandingkan dengan jenis LCC lainnya seperti Pueraria phaseoloides, Centrosema pubescent dan Pueraria javanica. Menurut Harahap dkk (2008:30), tanaman penutup tanah Mucuna breacteata dapat menghasilkan bahan organik yang tinggi dengan jumlah serasah yang dihasilkan pada tempat ternaung sebanyak 9 ton (setara dengan $263 \mathrm{~kg}$ NPKMg dengan 45$56 \% \mathrm{~N}$ ) dan di daerah terbuka sebanyak 20 ton (setara dengan $531 \mathrm{~kg}$ NPKMg dengan 75-83\% $\mathrm{N})$. Tingginya bahan organik dan hara pada LCC $\mathrm{Mb}$ ini, maka perlu dilakukan penelitian dengan tujuan untuk mengetahui pengaruh pemberian LCC Mb terhadap pertumbuhan dan hasil sawi hijau pada tanah PMK, serta mengetahui dosis LCC Mb yang menghasilkan pertumbuhan serta hasil sawi hijau tertinggi pada tanah PMK.

\section{HASIL DAN PEMBAHASAN}

\section{Hasil Penelitian}

\section{Tinggi Tanaman}

Tinggi tanaman diukur menggunakan meteran mulai dari pangkal batang sampai daun yang terpanjang. Data hasil pengukuran tinggi

\section{METODOLOGI PENELITIAN}

Penelitian dilakukan di lapangan dengan menggunakan Rancangan Acak Kelompok (RAK) non faktorial. Perlakuannya adalah LCC Mucuna bracteata (LCC Mb) yang terdiri dari 7 (tujuh) taraf perlakuan dan tiap taraf diulang 4 (empat) kali. Taraf perlakuannya yaitu: $\mathrm{L}_{0}=$ kontrol; $\mathrm{L}_{1}$ $=0,5 \mathrm{~kg}$ LCC Mb per $\mathrm{m}^{2} ; \mathrm{L}_{2}=1 \mathrm{~kg}$ LCC Mb per $\mathrm{m}^{2} ; \mathrm{L}_{3}=1,5 \mathrm{~kg}$ LCC Mb per $\mathrm{m}^{2} ; \mathrm{L}_{4}=2 \mathrm{~kg}$ LCC $\mathrm{Mb}$ per $\mathrm{m}^{2} ; \mathrm{L}_{5}=2,5 \mathrm{~kg} \mathrm{LCC} \mathrm{Mb}$ per $\mathrm{m}^{2} ; \mathrm{L}_{6}=3 \mathrm{~kg}$ LCC Mb per $\mathrm{m}^{2}$.

Jumlah tanaman dalam satu petak $\left(\mathrm{m}^{2}\right)$ sebanyak 9 tanaman sehingga dalam satuan percobaan terdapat 252 tanaman. Tanaman pengamatan diambil 3 (tiga) tanaman dalam tiap petak percobaan, sehingga diperoleh seluruh tanaman pengamatan ada 84 tanaman. Bahan penelitian terdiri dari: tanaman LCC Mucuna bracteata dan benih sawi hijau varietas tosakan. Peubah yang diamati yaitu tinggi tanaman, jumlah daun dan berat segar tanaman. Data yang diperoleh dianalisis dengan menggunakan analisis sidik ragam. Jika hasil analisis menunjukan ada pengaruh perlakuan yang diberikan terhadap peubah yang diamati, maka dilanjutkan dengan uji BNJ untuk mengetahui taraf perlakuan mana yang terbaik. Penelitian ini dilaksanakan di Desa Perongkan Kecamatan Sekadau Hulu Kabupaten Sekadau.

tanaman dianalisis menggunakan analisis sidik ragam, yang hasilnya dapat dilihat pada Tabel 1 .

Tabel 1 Hasil Analisis Sidik Ragam (ANSIRA) pengaruh pemberian LCC Mb terhadap tinggi tanaman (cm) sawi hijau

\begin{tabular}{lcccccc}
\hline \multicolumn{1}{c}{ SK } & DB & JK & KT & F & 0.05 & 0.01 \\
\hline Ulangan & 3 & 5,89 & 1,96 & $0,99^{\text {tn }}$ & 3,16 & 5,09 \\
Perlakuan & 6 & 378,10 & 63,02 & $31,70^{* *}$ & 3,66 & 4,01 \\
Galat & 18 & 35,78 & 1,99 & & & \\
\hline Total & 27 & 419,76 & & kk $=$ & $7,04 \%$ & \\
\hline
\end{tabular}

Keterangan : **= pengaruh nyata pada taraf 0,01

tn = pengaruh tidak nyata pada taraf 0,05 
Hasil analisis sidik ragam (Tabel 1) menunjukkan bahwa pemberian LCC Mb sangat berpengaruh terhadap tinggi tanaman. Untuk mengetahui perbedaan pengaruh antar taraf LCC $\mathrm{Mb}$ dilanjutkan dengan uji BNJ pada taraf nyata 5 $\%$ dan $1 \%$ yang disajikan pada Tabel 2.

Tabel 2 Hasil Uji BNJ Pengaruh LCC Mb terhadap Tinggi Tanaman Sawi hijau

\begin{tabular}{cccccccc}
\hline Perlakuan & Rerata & Beda & & & & & \\
\hline $\mathrm{L}_{0}$ & $15,42 \mathrm{a}$ & - & & & & & \\
$\mathrm{L}_{2}$ & $17,17 \mathrm{~b}$ & $1,75^{*}$ & - & & & & \\
$\mathrm{L}_{1}$ & $17,58 \mathrm{bc}$ & $2,17^{* *}$ & $0,42^{\text {tn }}$ & - & & & \\
$\mathrm{L}_{3}$ & $18,92 \mathrm{c}$ & $3,50^{* *}$ & $1,75^{*}$ & $1,33^{\text {tn }}$ & - & & \\
$\mathrm{L}_{4}$ & $20,67 \mathrm{~d}$ & $5,25^{* *}$ & $3,50^{* *}$ & $3,08^{* *}$ & $1,75^{*}$ & - & \\
$\mathrm{L}_{5}$ & $23,83 \mathrm{e}$ & $8,42^{* *}$ & $6,67^{* *}$ & $6,25^{* *}$ & $4,92^{* *}$ & $3,17^{* *}$ & - \\
$\mathrm{L}_{6}$ & $26,58 \mathrm{f}$ & $11,17^{* *}$ & $9,42^{* *}$ & $9,00^{* *}$ & $7,67^{* *}$ & $5,92^{* *}$ & $2,75^{* *}$ \\
\hline
\end{tabular}

BNJ $0,05=1,51$

BNJ $0,01=1,90$

Keterangan : $*$ = beda nyata pada taraf 0,05

$$
\begin{aligned}
& * *=\text { beda nyata pada taraf } 0,01 \\
& \text { tn }=\text { beda tidak nyata pada taraf } 0,05
\end{aligned}
$$

Hasil uji BNJ (Tabel 2) menunjukkan bahwa tinggi tanaman mengikuti taraf pemberian LCC Mb. Tinggi tanaman semakin bertambah tinggi seiring dengan bertambahnya dosis LCC Mb. Tinggi tanaman tidak berbeda nyata pada pemberian LCC Mb sebanyak $1 \mathrm{~kg}\left(\mathrm{~L}_{2}\right)$ dengan pemberian $0,5 \mathrm{~kg}\left(\mathrm{~L}_{1}\right)$, selisih hanya $0,42 \mathrm{~cm}$.

\section{Jumlah Daun}

Jumlah daun dihitung bersamaan dengan pengukuran tinggi tanaman. Daun yang dihitung adalah daun yang sudah terbuka sempurna. Data hasil penghitungan jumlah daun dianalisis menggunakan analisis sidik ragam, yang hasilnya dapat dilihat pada Tabel 3.

Tabel 3 Hasil Analisis Sidik Ragam (ANSIRA) pengaruh pemberian LCC Mb terhadap jumlah daun (helai) sawi hijau

\begin{tabular}{lcccccc}
\hline \multicolumn{1}{c}{ SK } & DB & JK & KT & F & 0.05 & 0.01 \\
\hline Ulangan & 3 & 1,60 & 0,53 & $2,16^{\text {tn }}$ & 3,16 & 5,09 \\
Perlakuan & 6 & 32,28 & 5,38 & $21,75^{* *}$ & 3,66 & 4,01 \\
Galat & 18 & 4,45 & 0,25 & & & \\
\hline Total & 27 & 38,33 & & $\mathrm{kk}=$ & $4,20 \%$ & \\
\hline
\end{tabular}

Keterangan : $* *=$ pengaruh nyata pada taraf 0,01

tn $=$ pengaruh tidak nyata pada taraf 0,05

Hasil analisis sidik ragam (Tabel 3) menunjukkan bahwa pemberian LCC Mb sangat berpengaruh terhadap jumlah daun. Untuk Tabel 4 Hasil Uji BNJ Pengaruh LCC Mb terhadap J mengetahui perbedaan pengaruh antar taraf LCC Mb dilanjutkan dengan uji BNJ pada taraf nyata 5

\begin{tabular}{|c|c|c|c|c|c|c|c|}
\hline Perlakuan & Rerata & Beda & & & & & \\
\hline $\mathrm{L}_{0}$ & $9,67 \mathrm{a}$ & & & & & & \\
\hline $\mathrm{L}_{1}^{0}$ & $11,08 \mathrm{~b}$ & $1,42^{* *}$ & - & & & & \\
\hline $\mathrm{L}_{2}$ & $11,83 \mathrm{~b}$ & $2,17^{* *}$ & $0,75^{\text {tn }}$ & - & & & \\
\hline $\mathrm{L}_{3}^{2}$ & $12,17 \mathrm{bc}$ & $2,50^{* * *}$ & $1,08^{* * *}$ & $0,33^{\text {tn }}$ & - & & \\
\hline $\mathrm{L}^{3}$ & $12.33 \mathrm{bc}$ & $2,67^{* *}$ & $1,25^{* *}$ & $0,50^{\mathrm{tn}}$ & $0,17^{\mathrm{tn}}$ & - & \\
\hline $\mathrm{L}_{5}^{4}$ & $12.50 \mathrm{c}$ & $2,83^{* *}$ & $1,42^{* *}$ & $0,67^{* *}$ & $0,33^{\text {tn }}$ & $0,17^{\mathrm{tn}}$ & - \\
\hline $\mathrm{L}_{6}$ & $13,25 \mathrm{~d}$ & $3,58^{* *}$ & $2,17^{* *}$ & $1,42^{* *}$ & $1,08^{* *}$ & $0,92^{* *}$ & $0,75^{* *}$ \\
\hline
\end{tabular}
$\%$ dan $1 \%$ yang disajikan pada Tabel 4 .

$\mathrm{BNJ} 0.05=0.53$

Keterangan : ${ }^{* *}=$ beda nyata pada taraf 0,01

tn = beda tidak nyata pada taraf 0,05

PIPER No. 31 Volume 16 Oktober 2020 
Uji BNJ (Tabel 4) menunjukkan bahwa jumlah daun tanaman yang diberi $3 \mathrm{~kg}\left(\mathrm{~L}_{6}\right) \mathrm{LCC}$ $\mathrm{Mb}$ menghasilkan jumlah daun tertinggi dari tanaman lain dengan rata-rata jumlah daun 13,25 helai per tanaman.

\section{Berat Segar Tanaman}

Berat segar tanaman ditimbang pada saat tanaman dipanen. Sebelum ditimbang terlebih dahulu akarnya dibuang dan dibersihkan dari tanah yang melekat pada permukaan daun. Data hasil penimbangan berat segar tanaman dianalisis menggunakan analisis sidik ragam, yang hasilnya dapat dilihat pada Tabel 5.

Tabel 5 Hasil Analisis Sidik Ragam (ANSIRA) Pengaruh Pemberian LCC Mb terhadap Berat Segar Tanaman (kg) Sawi Hijau

\begin{tabular}{llccccc}
\hline \multicolumn{1}{c}{ SK } & DB & JK & KT & F & 0.05 & 0.01 \\
\hline Ulangan & 3 & 0,00016 & 0,00005 & $1,71^{\text {tn }}$ & 3,16 & 5,09 \\
Perlakuan & 6 & 0,00867 & 0,00144 & $45,37^{* *}$ & 3,66 & 4,01 \\
Galat & 18 & 0,00057 & 0,00003 & & & \\
\hline Total & 27 & 0,01 & & $\mathrm{kk}=$ & $9,77 \%$ & \\
\hline
\end{tabular}

Keterangan : **= pengaruh nyata pada taraf 0,01

tn $=$ pengaruh tidak nyata pada taraf

0,05

Hasil analisis sidik ragam (Tabel 5) menunjukkan bahwa pemberian LCC Mb sangat berpengaruh terhadap berat segar tanaman. Untuk mengetahui perbedaan pengaruh antar taraf LCC $\mathrm{Mb}$ dilanjutkan dengan uji BNJ pada taraf nyata 5 $\%$ dan $1 \%$ yang disajikan pada Tabel 6.

Tabel 6 Hasil Uji BNJ Pengaruh LCC Mb terhadap Berat Segar Sawi hijau

\begin{tabular}{clllllll}
\hline Perlakuan & Rerata & Beda & & & & & \\
\hline $\mathrm{L}_{0}$ & $0,036 \mathrm{a}$ & - & & & & & \\
$\mathrm{L}_{1}$ & $0,040 \mathrm{a}$ & $0,004^{\text {tn }}$ & - & & & & \\
$\mathrm{L}_{2}$ & $0,051 \mathrm{~b}$ & $0,015^{* *}$ & $0,011^{* *}$ & - & & & \\
$\mathrm{L}_{3}$ & $0,053 \mathrm{~b}$ & $0,018^{* *}$ & $0,013^{* *}$ & $0,003^{\text {tn }}$ & - & & \\
$\mathrm{L}_{4}$ & $0,064 \mathrm{c}$ & $0,028^{* *}$ & $0,024^{* *}$ & $0,013^{* *}$ & $0,011^{* *}$ & - & \\
$\mathrm{L}_{5}$ & $0,068 \mathrm{c}$ & $0,033^{* *}$ & $0,028^{* *}$ & $0,018^{* *}$ & $0,015^{* *}$ & $0,004^{\text {tn }}$ & - \\
$\mathrm{L}_{6}$ & $0,092 \mathrm{~d}$ & $0,056^{* *}$ & $0,052^{* *}$ & $0,041^{* *}$ & $0,038^{* *}$ & $0,028^{* *}$ & $0,023^{* *}$ \\
\hline
\end{tabular}

BNJ $0,05=0,006$ BNJ $0,01=0,008$

Keterangan : $* *=$ beda nyata pada taraf 0,01

tn = beda tidak nyata pada taraf 0,05

Uji BNJ (Tabel 6) menunjukkan bahwa berat segar tanaman yang diberi perlakuan $3 \mathrm{~kg}$ $\left(\mathrm{L}_{6}\right)$ LCC Mb menghasilkan berat segar tertinggi dari tanaman lain dengan rata-rata berat $0,092 \mathrm{~kg}$ per tanaman.

\section{Pembahasan}

Pemberian LCC Mb sangat berpengaruh terhadap pertumbuhan dan hasil tanaman sawi hijau, yang dapat dilihat dari tinggi tanaman, jumlah daun, dan berat segar tanaman. Umumnya pertumbuhan dan hasil tanaman dapat tumbuh dan memberikan hasil yang baik disebabkan oleh ketersediaan hara PIPER No. 31 Volume 16 Oktober 2020 yang cukup serta pemeliharaan yang baik. Dalam penelitian ini, penambahan hara dilakukan dengan pembenaman LCC Mb. LCC Mb merupakan salah satu jenis pupuk hijau yang mengandung nitrogen cukup tinggi karena bintil akar yang terdapat pada tanaman LCC Mb ini. Selain mengandung nitrogen pupuk hijau LCC Mb juga mengandung $\mathrm{C}$-organik sehingga dapat memperbaiki sifat-sifat tanah, dan melepaskan unsur-unsur hara yang terikat oleh koloid tanah melalui bantuan mikroorganisme. Hanafiah, dkk (2005:137-140) menjelaskan bahwa perbaikan 
kondisi biologi tanah akan meningkatkan pertumbuhan dan hasil tanaman. Hakim, dkk (1986:121) menjelaskan bahwa kondisi biologi tanah yang membaik akan memperbaiki tata udara dalam tanah, akibat selanjutnya pertumbuhan tanaman akan meningkat.

Hasil uji BNJ diketahui bahwa pemberian $3 \mathrm{~kg}\left(\mathrm{~L}_{6}\right) \mathrm{LCC} \mathrm{Mb}$ memberikan hasil tertinggi terhadap tinggi tanaman, jumlah daun dan berat segar tanaman. Pemberian $3 \mathrm{~kg}$ LCC $\mathrm{Mb}$ merupakan taraf perlakuan yang tertinggi dari taraf perlakuan lainnya. Hal ini tentu menyebabkan tanah menjadi lebih baik terutama ketersediaan bahan organik. Ketersediaan bahan organik akan memperbaiki sifat fisik, kimia dan biologi tanah. Tanah menjadi gembur, mikroorganisme dapat bekerja dengan aktif dan akhirnya ketersediaan hara akan meningkat, terutama hara N. Dalam kondisi tanah seperti ini, akan memberikan pertumbuhan yang baik pada tanaman yang tumbuh diatasnya. Baik pertumbuhan tinggi maupun pertambahan jumlah daun. Pracaya (2013:13) menjelaskan bahwa pupuk hijau Leguminose dapat menambah unsur $\mathrm{N}$ dalam tanah karena memiliki rhizobium yang mampu mengikat unsur $\mathrm{N}$ dari udara.

Menurut Hardjowigeno (2007:82). N berperan dalam memperbaiki pertumbuhan vegetatif tanaman. Havlin et al. (2005:101) menambahkan bahwa $\mathrm{N}$ merupakan penyusun asam amino yang selanjutnya bergabung membentuk protein dan asam nukleat. Selain membentuk protein, $\mathrm{N}$ merupakan bagian integral dari klorofil yang mengubah cahaya menjadi energi kimia yang diperlukan untuk fotosintesis.

Fotosintesis sebagai proses metabolisme tumbuhan dalam pembentukan karbohidrat tidak terlepas dari pertumbuhan vegetatif tanaman sebelumnya. Pertumbuhan vegetatif yang baik akan mempengaruhi pertumbuhan generatif selanjutnnya. Dalam penelitian ini tanaman sawi hijau tumbuh baik pada taraf perlakuan $3 \mathrm{~kg} \mathrm{LCC}$ Mb. Hasil uji BNJ menunjukkan bahwa pemberian $3 \mathrm{~kg}$ LCC Mb ini juga menghasilkan berat segar tanaman tertinggi. Hal ini disebabkan karena unsur hara yang terdapat dalam LCC Mb mampu

PIPER No. 31 Volume 16 Oktober 2020 mengoptimalkan pertumbuhan tanaman yang juga berpengaruh terhadap hasil tanaman dalam hal ini adalah berat tanaman.

Menurut Jumin (1991:40) hasil tanaman adalah akumulasi dari pertumbuhan tanaman secara keseluruhan. Meningkatnya hasil tanaman tidak lepas dari status hara yang digunakan dan diperlukan oleh tanaman. Sarief (1986:43) menjelaskan bahwa unsur hara seperti N, P, K, dan unsur hara mikro penting bagi tanaman. Hasbiah dan Wahidah (2013:67) menyatakan bahwa pada pupuk organik unsur hara yang terkandung yaitu Karbon (C), Nitrogen (N), Fosfor (P) dan Kalium (K) serta beberapa unsur hara mikro seperti Magnesium ( $\mathrm{Mg}$ ) dan Kalsium (Ca). Tanaman memerlukan unsur hara yang cukup dalam melakukan berbagai proses metabolisme salah satunya yaitu proses fotosintesis. Penggunaan pupuk organik dapat membantu dalam penyediaan unsur P dalam tanah yang sangat dibutuhkan dalam proses fotosintesis..

\section{KESIMPULAN}

Pemberian LCC Mb berpengaruh terhadap pertumbuhan dan hasil tanaman sawi hijau pada tanah PMK. Pemberian $3 \mathrm{~kg}$ LCC Mb menghasilkan pertumbuhan dan hasil tertinggi tanaman sawi hijau dengan tinggi rata-rata 26,58 $\mathrm{cm}$, jumlah daun 13,25 helai, dan berat segar tanaman $0,092 \mathrm{~kg}$ per tanaman.

\section{SARAN}

Untuk meningkatkan pertumbuhan dan hasil tanaman sawi hijau pada tanah PMK dapat diberikan LCC Mb dengan dosis $3 \mathrm{~kg}$ per $\mathrm{m}^{2}$. Perlu dilakukan penelitian lanjutan dengan dosis $\mathrm{LCC} \mathrm{Mb}$ yang lebih tinggi agar diperoleh pertumbuhan dan hasil tanaman sawi hijau yang optimal pada tanah PMK.

\section{DAFTAR PUSTAKA}

Anonim. 2016. Peran Pupuk Hijau dalam

Mendukung Pertanian Organik. Artikel

Pertanian online. www.google.com.

Badan Pusat Statistik Kalimantan Barat. 2015.

Kalimantan Barat DalamAngka.

Pontianak: BPS Kalbar. 
Hakim, N. Nyakpa, M.Y. Lubis, A.M., Nugroho, S.G. Saul, M.R., Diha, M.A., Hong, G.B., Balley, H.H. 1998. Dasar-Dasar Ilmu T anah. Lampung: Universitas Lampung.

Hanafiah, K.A., I. Anas., A. Napoleon., N. Gofar. 2005. Biologi Tanah, Ekologi dan Makrobiologi Tanah. Jakarta: Raja GrafindoPersada.

Harahap, S.N. Kairul. Surio,T dan Tompul, S. 2008. Tanaman Penutup Tanah Peningkat Produksi Perkebunan. Universitas Sumatera Utara. Medan.

Hardjowigeno S.2007. Ilmu Tanah. Jakarta: Akademika Pressindo.

Hasbiah ST dan Wahidah BF. 2013. Perbandingan Kecepatan Fotosintesis Pada Tanaman Sawi Hijau (Brassica juncea) yang diberi Pupuk Organik dan Anorganik. Biogenesis. Vol 1, No. 1, Juni 2013, hal 61-69
Havlin JL, Beaton JD, Tisdale SL, Nelson WL. 2005. Soil Fertility and Fertillizer, Ed ke-7. New Jersey: Pearson Education Inc.

Jumin, H.B. 1991. Dasar-Dasar Agronomi. Jakarta: Rajawali Press.

Rambe, TR., Sampoerna., GME. Manurung. 2012. Compost LCC Mucuna bracteata and NPK Tablet Fertilizer Application On The growth Of Oil Palm Seedlings (Elaeis guineensi Jacq) In The Main Nursery. Jurusan Agroteknologi Fakultas Pertanian Universitas Riau.

Rinsema. 1993. Kesuburan Tanah. Jakarta: RhinekaCipta.

Sarief, S. 1986. Kesuburan dan Pemupukan Tanah Pertanian. Bandung: Pustaka Buana. 